\title{
INFLUENCE OF METEOROLOGICAL FACTORS ON MAIZE PERFORMANCE IN LATVIA
}

\author{
Zinta Gaile\# and Irina Arhipova \\ Latvia University of Agriculture, Lielā iela 2, Jelgava, LV-3001, LATVIA, \\ zinta.gaile@llu.lv \\ \# Corresponding author
}

Contributed by Zinta Gaile

\begin{abstract}
Latvia is recognised as a marginal area for growing of maize (Zea mays L.), as years of high yielding can be broken by years with failures. The aim of this paper is to describe maize yield, dry matter (DM) content in fresh yield, and some other quality indicators in silage maize field trials at the Research and Study Farm "Vecauce" of the Latvia University of Agriculture $\left(56^{\circ} \mathrm{N}\right)$, in relation to temperature and moisture conditions. The study was carried out for 15 years (1999-2013). In total, 217 maize hybrids, belonging mainly to the early-maturity group (FAO up to 220), were investigated. Meteorological conditions considerably differed, and, according to heat conditions, only 10 years were suitable for maize production. The mean fresh maize yield varied from 43.01 $t$ ha ${ }^{-1}$ to $63.39 t$ ha $^{-1}$ during the study period, which is 1.8 to 2.9 times higher than the average statistical yield in Latvian farms in the respective years. The DM yield ranged between $8.77 \mathrm{tha}^{-1}$ (in 2004) and $20.05 \mathrm{t} \mathrm{ha}^{-1}$ (in 2013) and was significantly correlated with temperature in May and June. The study suggested that cold tolerance of hybrids during early development stages should be investigated in future. Fresh and DM yield of maize were significantly $(p<0.001)$ affected by hybrid and year as factors, as well as by their interaction. DM content in fresh yield was correlated with active temperature sum. Low precipitation was a yield-limiting factor during some years. Ear proportion in yield decreased when moisture stress occurred before and during silking.
\end{abstract}

Key words: maize yield, quality, hybrid, temperature, water stress.

\section{INTRODUCTION}

Maize (Zea mays L.) as a forage crop has been known in Latvia since the late 19th century, but its growing was noted more widely only after the First World War. A very extensive growing of maize, and, simultaneously, broad research into different aspects of maize production, started in the 1950 s, which was enforced by the leader of the former Soviet Union N. Khrushchev (the area sown with maize reached more than 100 thousand ha in certain years, e.g. 1955, 1962, and 1963). Very thorough research on different aspects of maize growing, ensiling and feeding was carried out until the 1970s-1980s (Gaile, 2009). After 1990, the area sown with maize decreased sharply due to several reasons, including low demand for forage due to decrease in the number of cattle, and land reform. Lack of knowledge and equipment was noted in new farms, and shortage of seeds of suitable hybrids occurred for several years. The lowest point was 1995, when only 600 ha were sown with maize. The area with maize (mostly for forage production) started to increase markedly from 2006, particularly after 2008 , when many farmers began to grow it for biogas production (20.6 and 20.4 thousand ha in 2012 and 2013, respectively) (Central Statistical Bureau of Latvia: http://www.csb.gov.lv/en/dati/statistics-database-30501.html). Currently, in Latvia, 29 biogas stations utilise substrates (including maize) produced in agriculture. Statistical yield of maize, available as fresh maize yield, is typically low (weighted mean $19.0 \mathrm{t} \mathrm{ha}^{-1}$ during the period 1955-2013). The highest fresh maize yields, close to $30 \mathrm{t} \mathrm{ha}^{-1}$, were harvested in nine years (including 2013) of 58 surveyed. Fresh maize yields are difficult to compare when dry matter (DM) content is not known. Nowadays, more suitable hybrids with a higher DM content at harvest are grown. Especially important is the development of the so-called early-maturing hybrids that can be grown with good success (achieving an adequate DM yield and quality in changing meteorological conditions). Improvements in maize yield and quality have been made by breeding maize in traditional growing areas, e.g. in Corn Belt in USA (Lauer et al., 2001), as well as in short-season areas (Baron et al., 2008). Also, discussion on the characteristics differentiating silage maize from grain maize indicates that the best grain-maize hybrids are not always the most suitable for silage (Barriere et al., 1997; Coors and Lauer, 2000).

As maize is a crop of southern origin, in Latvia, located in northern latitudes $\left(55^{\circ} 40^{\prime}-58^{\circ} 05^{\prime} \mathrm{N}\right)$, temperature is one of 
the most limiting factors affecting maize DM yield, DM content in fresh yield, and other important quality parameters (e.g. concentration of neutral detergent fibre (NDF), acid detergent fibre (ADF), starch, and protein). Studies have shown that breeding of maize for stress tolerance at suboptimal temperatures in regions of cool temperate climates, including northern Europe, is one of the key factors for successful growing of the crop (Greaves, 1996; Tollenaar and $\mathrm{Wu}, 1999)$.

Many studies have shown that global climate change can extend the thermal growing season in northern Europe, which might be beneficial for maize growing (Olesen, 2005; Peltonen-Sainio et al., 2009; Olesen et al., 2011). Climate change can also bring unpredictable extremes, e.g. periods with very high temperatures, drought, and excess periodical precipitation. Therefore, growers need to consider yield limitation of maize caused by water deficit.

Maize silage is a high-quality feed for livestock and a substrate for biogas reactors, not only during winter but throughout the year. There is also interest in maize silage in marginal growing areas (Mussadiq et al., 2012), including Latvia. Since new improved hybrids are offered by breeders each year and changes in the seed market are frequent, one of the never-ending targets is evaluation of hybrids in field conditions to help producers choose the most suitable in the regional conditions. Long-term maize research using modern early-maturing hybrids is needed to determine the effect of meteorological conditions on crop yield and quality.

The aim of this paper was to determine maize yield, DM content in fresh yield and some other maize quality indica- tors, in relation to meteorological factors, in silage maize field trials conducted at a northern latitude $\left(56^{\circ} \mathrm{N}\right)$ over a period of 15 years (1999-2013).

\section{MATERIALS AND METHODS}

Field trials were conducted to evaluate maize performance using a total of 217 different maize hybrids at the Research and Study farm "Vecauce" (latitude: $56^{\circ} 28^{\prime} \mathrm{N}$; longitude: $22^{\circ} 53^{\prime} \mathrm{E}$ ) of the Latvia University of Agriculture from 1999 until 2013 (Table 1). In this comparison, 40 hybrids were included for 3-8 years, and 177 hybrids for 1-2 years. Original seed was always used. The hybrids were obtained from European (including Ukraine) and American maize breeding companies. Most of them belonged to the early-maturity maize group (FAO number $<220$ for the hybrids of European origin; relative maturity $<70-85$ days for American hybrids). Starting in 2002, some later-maturity hybrids (FAO number < 350) were included (during 2002-2004 hybrids of Ukrainian origin; and during 2005-2013 — hybrids from the EU breeding companies). The hybrids were arranged in four times replicated randomised blocks; plot size was $4.2 \mathrm{~m}^{2}$ in 1999 , and $16.8 \mathrm{~m}^{2}$ in all other years (four rows, each $70 \mathrm{~cm}$ apart). An exception with 10 hybrids occurred in 2002, when they were arranged in three times replicated randomised blocks with the same plot size as for other hybrids. For thirteen years soil in the plots was Calcaric Luvic Epigleyic Phazeozem, fine sandy loam with $\mathrm{pH} \mathrm{KCl} \mathrm{7.1,} \mathrm{available} \mathrm{P} \mathrm{concentration} 252 \mathrm{mg} \mathrm{kg}^{-1}$, available $\mathrm{K}-198 \mathrm{mg} \mathrm{kg}^{-1}$, and humus concentration -25 $\mathrm{g} \mathrm{kg}^{-1}$. In 2009, the soil was Calcaric Luvic Endostagnic

Table 1

NUMBER OF MAIZE HYBRIDS* INCLUDED IN THE TRIAL, SOWING AND HARVESTING DATES, AND HERBICIDES USED FOR WEED CONTROL, DEPENDING ON TRIAL YEAR

\begin{tabular}{|c|c|c|c|c|}
\hline Trial year & $\begin{array}{l}\text { Number } \\
\text { of hybrids }\end{array}$ & Sowing date & Harvesting date & Herbicides for weed control \\
\hline 1999 & 19 & May 3 & Sept. 23 & Only mechanical weed control was done \\
\hline 2000 & 6 & May 9 & Sept. 29 & \multirow{4}{*}{$\begin{array}{l}\text { Metil-primisulfuron }(75 \%) 0.04 \mathrm{~kg} \mathrm{ha}^{-1}+ \\
\text { Dikamba }\left(480 \mathrm{~g} \mathrm{l}^{-1}\right) 0.11 \mathrm{ha}^{-1}\end{array}$} \\
\hline 2001 & 9 & May 8 & Sept. 25 & \\
\hline 2002 & 20 & May 7 & Sept. 17 & \\
\hline 2004 & 21 & May 12 & Oct. 4 & \\
\hline 2005 & 19 & May 5 & Sept. $20-21$ & \multirow{2}{*}{$\begin{array}{l}\text { Nicosulfuron }\left(40 \mathrm{~g} \mathrm{l}^{-1}\right) 1.01 \mathrm{ha}^{-1}+ \\
\text { Dicamba }\left(480 \mathrm{~g} \mathrm{l}^{-1}\right) 0.31 \mathrm{ha}^{-1}\end{array}$} \\
\hline 2006 & 24 & May 5 & Sept. 20-21 & \\
\hline 2007 & 31 & May 4 & Sept. $20-21$ & \multirow{2}{*}{$\begin{array}{l}\text { Tritosulfuron }\left(250 \mathrm{~g} \mathrm{~kg}^{-1}\right)+\text { Dicamba }\left(500 \mathrm{~g} \mathrm{~kg}^{-1}\right) 0.2 \mathrm{~kg} \mathrm{ha}^{-1}+ \\
\text { Rimsulfuron }\left(250 \mathrm{~g} \mathrm{l}^{-1}\right) 0.03 \mathrm{~kg} \mathrm{ha}^{-1}\end{array}$} \\
\hline 2008 & 29 & May 5 & Sept. 25 & \\
\hline 2010 & 32 & May 3 & Sept. $24-25$ & \multirow{3}{*}{$\begin{array}{l}\text { Foramsulfuron }\left(30 \mathrm{~g} \mathrm{l}^{-1}\right)+\text { Sodium methyl-iodosulfuron }\left(1 \mathrm{~g} \mathrm{l}^{-1}\right) 1.51 \mathrm{ha}^{-1}+ \\
2.4-\mathrm{D}\left(600 \mathrm{~g} \mathrm{l}^{-1}\right) 0.51 \mathrm{ha}^{-1}\end{array}$} \\
\hline 2011 & 44 & May 6 & Oct. 2 & \\
\hline 2012 & 39 & May 10 & Oct. 8 & \\
\hline 2013 & 41 & May 10 & Oct. 2-3 & $\begin{array}{l}\text { Florasulam }\left(16.7 \mathrm{~g} \mathrm{l}^{-1}\right)+\text { Mesotrione } 267\left(\mathrm{~g} \mathrm{l}^{-1}\right) 0.3 \\
1 \mathrm{ha}^{-1}+\text { Rimsulfuron }\left(250 \mathrm{~g} \mathrm{~kg}^{-1}\right) 0.05 \mathrm{~kg} \mathrm{ha}^{-1}\end{array}$ \\
\hline
\end{tabular}


Phazeozem (Anthric), sandy loam with $\mathrm{pH} \mathrm{KCl}$ 6.6, available $\mathrm{P}$ concentration $-129 \mathrm{mg} \mathrm{kg}^{-1}$, available $\mathrm{K}-143$ $\mathrm{mg} \mathrm{kg}^{-1}$, and humus concentration $-21 \mathrm{~g} \mathrm{~kg}^{-1}$. In 2012, the soil in plots was Endocalcaric Stagnic Phaeozem, clay loam with $\mathrm{pH} \mathrm{KCl} \mathrm{7.4,} \mathrm{available} \mathrm{P} \mathrm{concentration} \mathrm{-} 121 \mathrm{mg}$ $\mathrm{kg}^{-1}$, available $\mathrm{K}-146 \mathrm{mg} \mathrm{kg}^{-1}$, and humus concentration - $34 \mathrm{~g} \mathrm{~kg}^{-1}$. Pre-crops were cereals for grain in nine years, potato (Solanum tuberosum L.) in 2000, annual ryegrass (Lolium multiflorum L.) in 2006, 2007 and 2008, maize in 2011, and sunflower (Helianthus annuus L.) in 2013. Soil tillage was traditional, which included mould-board ploughing in previous autumn along with cultivation and rototilling before sowing in spring. Maize was sown mainly in the first ten-day period of May, which was considered the best sowing time (Gaile, 2012); however, in some years, a deviation from this time (Table 1) occurred due to unsuitable meteorological conditions. The sowing rate was from 71000 (in 1999-2002) to 83000 (in 2004-2013) seeds per ha, and only original seed was used. A special hand-operated planter was used for sowing. Weeds were controlled by herbicides at maize 3-6 leaf stage (except in 1999, when only weeding was done), and some weeding was done later in the season. Fertilisers applied before sowing were: $18 \mathrm{~kg}$ $\mathrm{ha}^{-1} \mathrm{~N}, 34 \mathrm{~kg} \mathrm{ha}^{-1} \mathrm{P}$, and $75 \mathrm{~kg} \mathrm{ha}^{-1} \mathrm{~K}$.

Nitrogen top-dressing (ammonium nitrate, 34\%) was done twice at total rate of $\mathrm{N} 130-140 \mathrm{~kg} \mathrm{ha}^{-1}$ divided among two times: (1) when herbicide effect on weeds was noticeable $\left(70 \mathrm{~kg} \mathrm{ha}^{-1} \mathrm{~N}\right)$, and (2) when maize reached height 50-60 $\mathrm{cm}$ tall $\left(60-70 \mathrm{~kg} \mathrm{ha}^{-1} \mathrm{~N}\right)$. Also foliar fertilisers were used in four trial years, when conditions visibly hindered maize development. On 8 July 1999, the microelement fertilizer Tenso Cocktail was sprayed at a rate of $1 \mathrm{~kg} \mathrm{ha}^{-1}$, when maize showed a lack of $\mathrm{Zn}$ and $\mathrm{Mg}$ due to drought. On 11 July 2006, Folicare N-P-K 18-18-18 + microelements 5 kg $\mathrm{ha}^{-1}$ were sprayed, also due to drought. In 2007, when many unidentified insects including aphids were observed feeding on maize, an insecticide (5 June: Thiamethoxam (250 g $\mathrm{kg}^{-1}$ ) $60 \mathrm{~g} \mathrm{ha}^{-1}$ ) and a foliar fertilizer (13 June: Folicare N$\mathrm{P}-\mathrm{K}$ 18-18-18 + microelements $5 \mathrm{~kg} \mathrm{ha}^{-1}$ ) were used. In 2009, a foliar fertilizer was used due to cool weather in May and June; however, even more favourable conditions in early July of that year did no promote growth, and it was decided to spray Folicare N-P-K 25-5-22 + microelements $7 \mathrm{~kg} \mathrm{ha}^{-1}$ twice (6 July and 17 July).

Maize was harvested in the third ten-day period of September or in the first ten-day period of October. Two middle rows were harvested for fresh maize yield determination, and samples were taken for analyses. In 1999-2009, plants were cut $15 \mathrm{~cm}$ above the soil surface and weighed, but, starting with 2010, a harvester HALDRUP M-63 was used, which also chopped and estimated the harvested yield and automatically took an mixed sample. Dry matter (DM) yield $\left(\mathrm{t} \mathrm{ha}^{-1}\right)$ was calculated from the fresh matter yield and DM content $(\%)$, which was determined according to the ISO 6496:1999 method. In 1999-2008, the proportion of DM yield of ears (grain + cob) in the whole-plant DM yield was calculated. The following yield quality indicators were determined: crude protein (CP) content (\%) was measured using the Kjeldahl method and coefficient 6.25 (LVS EN ISO 5983-2:2003); neutral detergent fibre (NDF) in DM (\%) was detgermined using the Forage analyses method 2.2.1.1.; acid detergent fibre (ADF) was determined using the Forage analyses method 4.1.; starch concentration was determined using the ISO 6493: 2000 method. Some parameters were calculated using formulas (1) and (2):

net energy for lactation: $\mathrm{NEL}, \mathrm{MJ} \mathrm{kg}^{-1}$ of

$\mathrm{DM}=(0.0245 \times \mathrm{DDM}-0.12) \times 4.184$,

where DDM is the digestible dry matter calculated from ADF:

DDM, $\mathrm{g} \mathrm{kg}^{-1} \mathrm{DM}=88.9-(0.779 \times \mathrm{ADF})$.

DM content was always determined for all hybrids, but other parameters were determined for all hybrids in 1999-2001 and 2005-2008. In other years, analyses were carried out for a smaller number of hybrids, and in 2002-2004 only for 3-6 hybrids, due to lack of funding. Analyses of starch concentration were carried out starting in 2009, when the number of CP analyses decreased to only some samples.

During the vegetation season, field germination was calculated as percentage of germinated seedlings from the sown seeds; phenological phases (emergence and silking) were defined as the time when $75 \%$ of plants entered the phase. The number of plants before harvesting was counted and recalculated on a hectare basis (detailed data of above-mentioned parameters are not shown). Plant height (m) was measured in each plot from the soil level up to the top of tassel for 30 successive plants in the same row in the period of 1999-2003, for 20 successive plants in 2004-2008, and for 15 successive plants in 2009-2013. Measurements were made in early September each year. All observations were carried out in the two middle rows.

Meteorological conditions differed between years (Table 2). Years with sum of active $\left(\geq 10{ }^{\circ} \mathrm{C}\right)$ temperatures (period from 1 May until 30 September) above $2000{ }^{\circ} \mathrm{C}$ were shown to be the most suitable for maize growing. Heat conditions were very good in eight years, good in two years (2005 and 2009), average in three years (2001, 2008, and 2012), and very bad in two years with the sum of active temperatures $1689{ }^{\circ} \mathrm{C}$ (2000) and $1874{ }^{\circ} \mathrm{C}$ (2004). Heat conditions were also characterised by mean monthly temperature in the maize vegetative period (Table 2). During some years, lack of precipitation was a yield-limiting factor (in six years only short periods occurred without precipitation, while the year 2006 till August was extremely hot and dry). To characterise moisture conditions, the Selyaninov's hydro-thermal coefficient (by formula (3)) was calculated for each month, for the whole vegetative period, and for the silking period (starting 10 days before silking (detailed data are not shown). The meteorological conditions are described in more detail in the Results section. 


\begin{tabular}{l|c|c|c|c|c|c|c|c|c|c|c|c}
\hline \multirow{2}{*}{ Year } & \multicolumn{9}{|c|}{ Temperature, ${ }^{\circ} \mathrm{C}$} & \multicolumn{5}{c}{ Precipitation, mm } \\
\cline { 2 - 12 } & May & June & July & Aug & Sept & Aver. & May & June & July & Aug & Sept & Sum \\
\hline 1999 & 11.2 & 17.7 & 18.6 & 16.0 & 13.6 & 15.4 & 30 & 44 & 39 & 65 & 30 & 208 \\
2000 & 11.5 & 13.7 & 15.2 & 14.5 & 9.3 & 12.8 & 62 & 33 & 78 & 46 & 69 & 288 \\
2001 & 11.0 & 12.6 & 19.1 & 16.3 & 11.7 & 14.2 & 37 & 170 & 124 & 75 & 108 & 514 \\
2002 & 14.5 & 15.8 & 18.8 & 19.5 & 12.2 & 16.1 & 16 & 100 & 174 & 0 & 35 & 325 \\
2003 & 12.0 & 14.3 & 19.7 & 16.1 & 11.9 & 14.9 & 16 & 49 & 44 & 115 & 36 & 260 \\
2004 & 10.2 & 13.3 & 15.8 & 17.3 & 12.3 & 13.8 & 43 & 118 & 116 & 69 & 82 & 428 \\
2005 & 11.2 & 14.3 & 18.3 & 16.1 & 13.3 & 14.7 & 43 & 49 & 65 & 106 & 36 & 298 \\
2006 & 11.6 & 16.2 & 20.1 & 17.5 & 13.9 & 15.9 & 28 & 24 & 13 & 150 & 46 & 261 \\
2007 & 12.3 & 16.6 & 16.3 & 17.9 & 11.9 & 15.0 & 52 & 49 & 102 & 60 & 76 & 339 \\
2008 & 11.3 & 14.6 & 17.1 & 16.4 & 10.6 & 14.0 & 24 & 44 & 57 & 90 & 15 & 230 \\
2009 & 11.5 & 13.7 & 17.1 & 15.8 & 12.9 & 14.2 & 18 & 95 & 136 & 39 & 40 & 328 \\
2010 & 11.9 & 14.6 & 20.8 & 18.2 & 10.8 & 15.2 & 73 & 38 & 132 & 133 & 78 & 454 \\
2011 & 11.3 & 16.8 & 18.8 & 16.1 & 12.5 & 15.1 & 48 & 40 & 150 & 151 & 32 & 421 \\
2012 & 11.7 & 13.8 & 17.3 & 15.2 & 12.2 & 14.1 & 38 & 58 & 133 & 96 & 26 & 351 \\
2013 & 14.2 & 17.2 & 17.2 & 16.6 & 11.3 & 15.3 & 111 & 28 & 81 & 62 & 91 & 373 \\
Norm & 11.2 & 15.2 & 16.6 & 16.0 & 11.5 & 14.1 & 43 & 51 & 75 & 75 & 59 & 303
\end{tabular}

* - data of temperature and precipitation were recorded directly on the research field by an automatic meteorological station, but long-term average data (norm) were taken from Dobele Hydrometeorological Station.

$H T C=\frac{R}{0.1 \times \sum t}$,

$\mathrm{R}$ - sum of precipitation in the period analysed;

$\sum t$ - sum of mean day-night temperatures in the same period.

The General Linear Model (GLM) Univariate procedure was used for analysis of variance for factorial design using IBM SPSS 16.0 software. Correlation and regression analyses were also used (MS Excel).

\section{RESULTS}

Maize yield. Mean fresh maize yield varied from 43.01 $\mathrm{t} \mathrm{ha}{ }^{-1}$ in 1999 up to $63.39 \mathrm{t} \mathrm{ha}^{-1}$ in 2007. DM yield varied from $8.77 \mathrm{t} \mathrm{ha}^{-1}$ in 2004) up to $20.05 \mathrm{t} \mathrm{ha}^{-1}$ in 2013 (Table $3)$. Tests of between-subjects effects demonstrated that fresh and DM yield of maize was significantly $(p<0.001)$ affected by hybrid and year as factors as well as by their interaction. An increasing trend of the mean maize DM yield per trial was observed from 1999 to 2013. Mean fresh and DM yields were correlated with mean plant height $(\mathrm{r}=$ 0.665 and 0.731 , respectively; $p<0.01$ ), which also depended on year, hybrid, and interaction of both $(p<0.01)$. The lowest plant height was observed in 2006, when drought occurred in May, June and July, and the highest in 2013 (Table 3). Fresh maize yield in our trials was 1.8 to 2.9 times higher than the average statistical yield in Latvian farms in the respective years.

DM yield was significantly correlated with seasonal sum of active temperatures $(r=0.599 ; p<0.05)$, mean seasonal temperature $(\mathrm{r}=0.533 ; p<0.05)$, and mean temperature in the May-June period ( $\mathrm{r}=0.785 ; p<0.01$; Fig. 1a).

Although temperature is the main limiting factor for maize yield in Latvia, our observations demonstrated that lack of
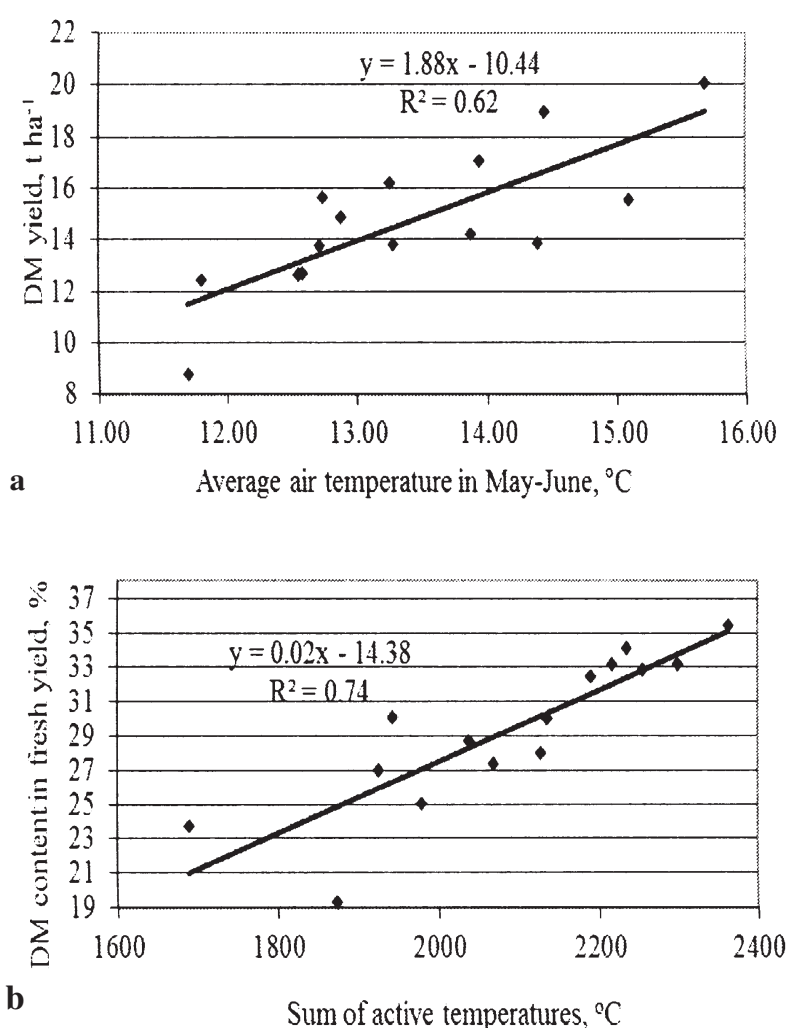

Fig. 1. DM yield depending on the mean air temperature in the period of May-June (a), and DM content in fresh maize yield depending on sum of active temperatures in the vegetative season (b) $(p<0.001)$. 
MEAN MAIZE YIELD PER TRIAL IN COMPARISON WITH MEAN STATISTICAL YIELD IN LATVIA, MEAN PLANT HEIGHT, AND SOME YIELD QUALITY PARAMETERS DEPENDING ON A TRIAL YEAR

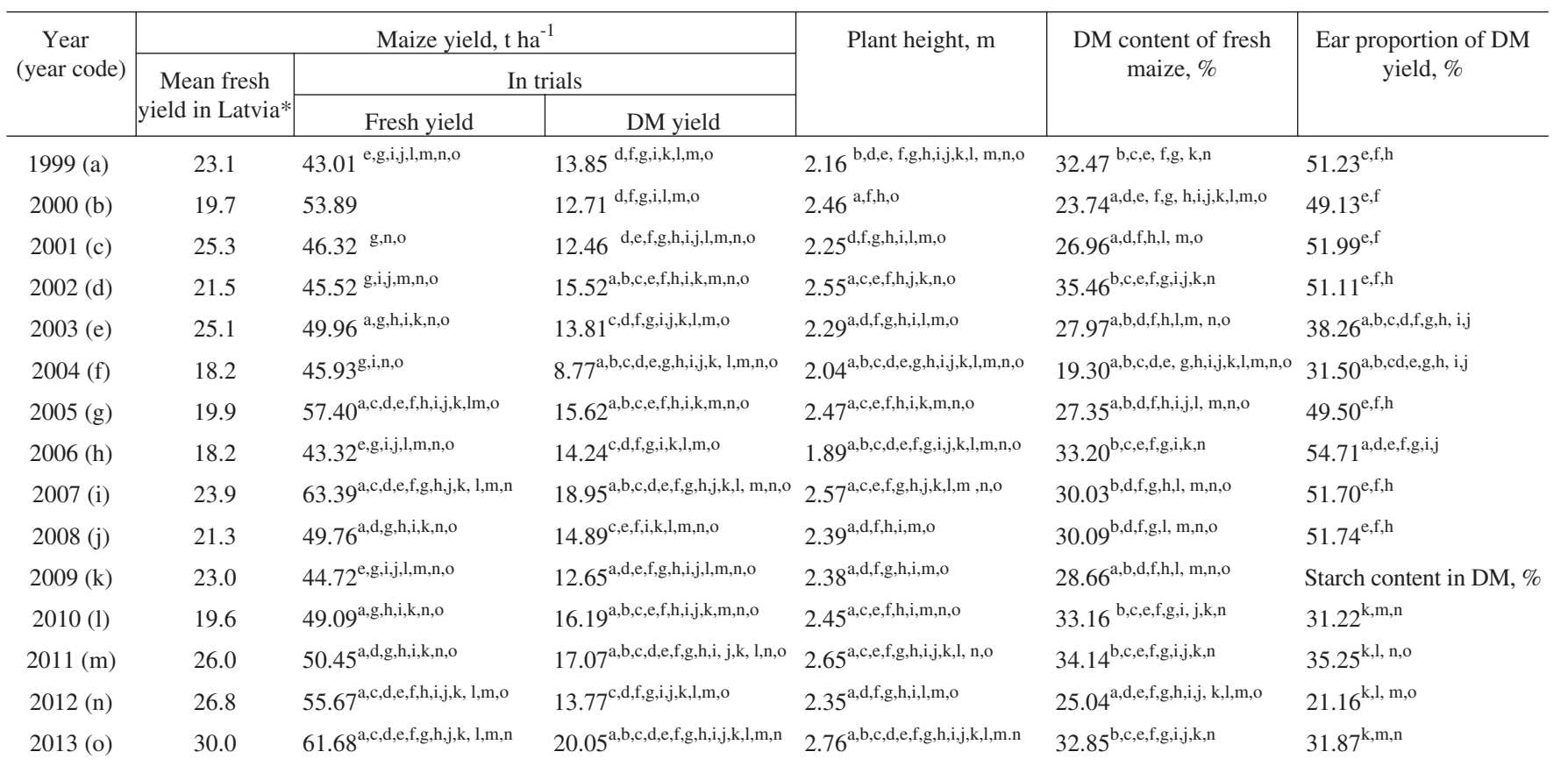

* - data obtained from the Central Statistical Bureau of Latvia: http://www.csb.gov.lv/en/dati/statistics-database-30501.html

Data throughout the same column significantly differ $(p<0.01)$ among the data mentioned with year codes in superscript $(\mathrm{a}, \mathrm{b}, \ldots, \mathrm{o})$.

moisture can also affect yield. For example, HTC was 0.9 calcultated for the growing season of 1999 , but during the silking period (including the previous 10 days when tasseling occurs), which is critical for maize yield formation, HTC was 0.3 in 1999, 0.1 in 2003, and 0.8 in 2008 and 2009. In 2006, HTC was 1.1 , which means "sufficiently wet", but May, June and July (HTC $-0.8,0.5$, and 0.2, respectively) were extremely dry and maize could not take advantage of the favourable temperatures. The best average maize DM yields were obtained in 2007 and 2013 (18.95 and $20.05 \mathrm{t} \mathrm{ha}^{-1}$, respectively), when favourable temperatures (sum of active temperatures 2136 and $2256{ }^{\circ} \mathrm{C}$, respectively) over the whole season were combined with uniform distribution of precipitation (HTC -1.5 and 1.6 during the whole season, respectively) (see Table 2 regarding monthly mean air temperature and sum of precipitation.

Maize quality. DM content in fresh maize yield at harvest varied from $19.30 \%$ (in 2004) to $35.46 \%$ (in 2002). DM content was significantly $(p<0.001)$ affected by hybrid (mainly regarding hybrid earliness) and meteorological conditions. The average lowest required DM level (25\%) was not reached in two years of 15 - in 2000 and 2004 (Table $3)$. In 2000, of the six hybrids investigated, only 'Husar' (FAO 180-190) achieved 26.02\% DM content. In 2004, none of the hybrids approached the $25 \%$ level of dry matter in maize fresh yield. DM content slightly lower than $28 \%$ (0.03 to 1.04 percent points) was recorded in 2001, 2003, and 2005. Although the earliness of investigated hybrids differed each year, almost all hybrids (with one or two ex- ceptions depending on the year) reached a DM content higher than $28 \%$ in seven years: 1999, 2002, 2006, 2007, 2010, 2011, and 2013. Mean DM content across all hybrids in a year was tightly correlated with sum of active temperatures $(r=0.862 ; p<0.01$, Fig. 1b), mean seasonal air temperature $(\mathrm{r}=0.836 ; p<0.01)$, and mean temperature in May-June $(\mathrm{r}=0.782 ; p<0.01)$.

Our results demonstrated that in six years of 10 (19992008 ), mean ear (grain plus cob) proportion was higher than $50 \%$ (Table 3$)$. This trait was significantly $(p<0.001)$ affected by year, hybrid, and their interaction. An extremely low ear proportion was obtained in 2003 (38.3\%; Table 3) due to drought during flowering (see HTC above). Another year with a very low $(31.5 \%)$ proportion of ears in the whole-plant DM yield was 2004. That year was characterised by conditions unfavourable for maize: poor heat conditions (especially May, June and July), and excessive precipitation in June and July (Table 2) together with atypical cloudy weather (very short sunny hours according to visual evaluation). Ear proportion of whole plant DM yield slightly lower than 50\% was observed in 2000 and 2005. The highest ear proportion $(54.7 \%)$ was observed in 2006 , which was an extremely dry year in the first part of the season. Due to drought, flowering of maize was delayed until the last days of July till early August, when moisture conditions were improved by heavy rain and HTC during flowering was 1.0.

Despite the various conditions, some hybrids showed a high proportion of ears, e.g. 'Loft' (mean 55.9\% in 1999-2002), 
'Tango' (mean 56.0\% in 2005-2008), and 'Celux' (mean $52.3 \%$ in 2005-2008). Other hybrids showed high variability in relation to temperature and moisture. For example, ear proportion of whole-plant DM yield for 'RM-011' was $59.6 \%$ in the warm year 2002, when HTC during flowering was 1.7, whereas in 2003 when temperature was unfavourable and HTC during flowering was only 0.1 , the ear proportion was only $37.1 \%$. Although mostly relatively good temperature conditions were observed in the second part of the vegetative season of all trial years, the lowest temperature was noted from the middle of July till 30 September in 2000, i.e. $12.7^{\circ} \mathrm{C}$, which was $1.7^{\circ} \mathrm{C}$ lower than the second lowest temperature (recorded in 2008). In that cold season, the ear proportion of whole-plant DM yield was only $49.1 \%$.

Crude protein concentration in maize DM was 6.7-8.7\%. Although the range of $\mathrm{CP}$ concentration was low, it was significantly affected by both year and hybrid $(p<0.001)$. The lowest CP was observed in 2007, when the second highest DM yield (18.95 $\mathrm{t} \mathrm{ha}^{-1}$ ) was achieved and ear proportion (51.7\%) was good, whereas the highest CP content was observed in 2001, when DM yield (12.46 t ha-1) was lower than the mean per trial period.

The average NDF concentration per year ranged between $41.09 \%$ (in 2001) and $53.41 \%$ (in 2003), and that of ADF ranged between $21.37 \%$ (in 2008) and 30.77 (in 2004). Both parameters were significantly $(p<0.01)$ influenced by hybrid and year as factors.

In our trials, energy concentration was measured as NEL. Mean annual NEL varied from 6.15 (2004) to 6.90 (2008) MJ kg-1 of DM. There was a significant impact of hybrid and year on the NEL concentration $(p<0.001)$. NEL was also correlated with ear proportion of whole-plant DM yield $(\mathrm{r}=0.741 ; p<0.05)$.

From 2009, also starch concentration in the biomass DM yield was evaluated. Mean starch concentration in maize yield varied from 21.16 (2012) to $35.25 \%$ (2011) (Table 3) and the effect of hybrid and year was significant $(p<$ $0.001)$.

\section{DISCUSSION}

Maize yield. The increasing trend of mean maize DM yield during 15 years can be explained by improved knowledge for choice of the most appropriate hybrids offered by the seed companies. At the same time breeding companies provided maize producers with hybrids better suited for silage in marginal areas, i.e. hybrids that were more stress (especially cold-stress) tolerant (Greaves, 1996; Barriere et al., 1997; Kosova et al., 2005) and more productive. It has been noted by several authors (e.g. Lauer et al., 2001) that maize forage yield has gradually increased due to breeding achievements and improved cultural practices. Barriere et al. (1997) reported that in France the increase in biomass yield of hybrids marked with the label "fit for silage" was
$0.17 \mathrm{t} \mathrm{ha}^{-1}$ per year during 11 years (late 1980s to early 1990s). Performance of silage maize in the northern latitudes is also affected by hybrid earliness (Crowley, 2005; Baron et al., 2008; Mussadiq et al., 2012). In the 1990s, mostly hybrids with a FAO number up to 200 (or even up to FAO 180) were considered to be suitable for growing in Latvia. However, more recent research indicated that also hybrids with a slightly later maturity (FAO up to 220) can perform well in in south-west of Latvia each year, if the suitable growing technologies are provided. The highest DM yield in our study was achieved by the hybrid 'ES Marco' (FAO 220) in 2013 (23.61 t ha ${ }^{-1}$ ). The same hybrid also demonstrated a high mean four-year yield (2010-2013) - $18.88 \mathrm{t} \mathrm{ha}^{-1}$. During the early part of our study period (1999-2006), in 2002, when heat conditions were most suitable for maize growing (Table 2), the record DM yield (19.28 $\mathrm{t} \mathrm{ha}^{-1}$ ) was achieved by hybrid 'Euro $401 \mathrm{CB}$ ' (FAO 350 - hybrid of an overly late maturity for Latvia).

The interaction effect of "hybrid $\times$ environmental factors" on maize yield observed in our research has been recorded also by other authors for similar latitudes $\left(55-60^{\circ} \mathrm{N}\right)$, e.g. Mussadiq et al. (2012). This can be explained by better performance of earlier hybrids in poor years or conditions, and superior performance by later-maturity hybrids in suitable conditions. Delayed sowing of late hybrids in poor years can also decrease the DM yield (Millner et al. 2005). We used hybrids with different-maturity in our study, they were exposed to possible unfavourable conditions in more or less diverse development stages, causing inconsistent effect on maize yield. For example, in 2007, when conditions for maize growing were very suitable and the 2 nd highest mean maize DM yield was obtained (18.95 $\mathrm{t} \mathrm{ha}^{-1}$; Table 3), while the hybrid 'RM-20' (FAO 180) had the lowest DM yield (13.32 $\mathrm{t} \mathrm{ha}^{-1}$ ), compared to its maximum yield $18.51 \mathrm{t} \mathrm{ha}^{-1}$ in 2002 and mean DM yield $15.42 \mathrm{t} \mathrm{ha}^{-1}$ for six years (2002-2003 and 2005-2008).

Better maize yields were obtained in warmer seasons. An important factor was temperature in the early season (May and June), which has been reported also by Stewart et al. (1998). Low temperature in the first part of the growing season significantly affected yield. Maize cold-stress tolerance in early growth stages is of particular importance (Greaves 1996, Barriere et al. 1997, Revilla et al. 2000, and Reimer 2010). Our trials suggest that cold tolerance of maize hybrids in early vegetative phases should be investigated in more detail in the conditions of Latvia. Generally, July and August have suitable temperatures for maize growing in Latvia, but in May and June, nights are usually cool, mean temperatures are low, and sometimes spring frosts occur. In 2002 and 2006, which generally were favourable for maize growing, spring frosts were observed on 20-21 May and on 1 June, respectively, when maize was not visibly affected but evidently suffered influencing the later formation of yield.

Many studies emphasise the importance of sufficient moisture availability during maize flowering (tasseling and silking) as well as in the period just after silking (Cakir, 2004; 
Ramadoss et al., 2004). In Nebraska, USA, hybrids developed in different years (1970s, early 1990s, and late 1990s) were observed to respond similarly to the varying water levels on average, but individual hybrids responded differently (O'Neil et al., 2004). In our study, the hybrid 'Nancis' (FAO 120) was markedly affected by drought in 2006, when its DM yield was only $13.30 \mathrm{t} \mathrm{ha}^{-1}$ (mean value for all hybrids that year $-14.24 \mathrm{t} \mathrm{ha}^{-1}$ (Table 3 ); in comparison, in 2007 this hybrid had a considerably higher DM yield $19.75 \mathrm{t} \mathrm{ha}^{-1}$, which was above the mean DM value $(18.95 \mathrm{t}$ $\mathrm{ha}^{-1}$ ) that year. Water stress in maize development can also lead to decreased plant height (Otegui et al., 1995; Cakir, 2004), as found also in Latvia (e.g. Gaile, 2012).

Although temperature and moisture are limiting factors for yield, nevertheless, the gap between the higher mean yield in our trials compared to the mean statistical yield on Latvian farms shows that improvement of growing technologies is needed. In Latvia, the effect of some maize yield-determining factors considered as important by researchers in other countries has not been investigated during the last decades, e.g. plant population density at harvest (Stanton et al., 2007; Baron et al., 2008), effect of seed size on yield (Sulewska et al., 2014), importance of crop rotation (Šeremešic et al., 2013) growing maize for silage, and possibility of minimising soil tillage (Avižienyte et al., 2013). Such investigations are needed also in Latvia, together with detailed research on maize fertilization. Our observations in production fields showed that also the sowing and harvesting schedule and the way of nitrogen top-dressing need to be improved.

Maize quality. For good quality silage, DM content in fresh maize yield at harvest is recommended to be higher than $28 \%$, but the requirement in Latvia is at least $25 \%$ of DM in fresh maize. Some improvement in DM content can be made by early sowing, and later harvesting (late September or early October) (Gaile, 2012). Also autumn frosts can desiccate leaves. A strong autumn frost during the 15-year trial period was observed only in 2005, on 17-18 September, when maize had to be harvested immediately to maintain the yield quality. In some other years, frosts were observed only in the first ten-day period of October, which did not hinder natural maize maturation. Correlation between DM content with sum of active temperatures, mean seasonal air temperature, and mean temperature in May-June indicated that temperature is the most important factor for maize growing in Latvia. Our results also suggest that global climate change will be beneficial to maize growing in Latvia during the next years or decades, as predicted by climate scientists (e.g. Olesen, 2005; Peltonen-Sainio et al., 2009; Olesen et al., 2011).

Another important characteristics of yield quality is ear proportion of whole-plant DM yield. Low ear proportion of whole plant DM yield occurred in 2003 due to drought during flowering, when maize is particularly sensitive to stress. Drought can also cause decreased grain number in ears (Setter et al., 2001; O'Neil et al., 2004). The year 2004 was cool, wet and atypically cloudy during the whole season.
Setter et al. (2001) have found that shade during flowering, similarly to water deficit, can decrease the number of kernels per ear. In our study, in 2004, mainly hybrids of too late maturity for Latvia's conditions were included in the trial: 11 out of 21 hybrids were characterized with a FAO number above 220. This trial showed that the coincidence of several maize yield- and quality-determining factors in their worst combination can lead to a complete maize-performance failure (Table 3), which growers need to consider.

Maize response to low temperatures during grain filling and maturation has not been widely investigated like the response to low temperatures during early growth stages. However, Ying et al. (2000) found that maize hybrids during grain filling differed essentially in the leaf carbon exchange rate response to cold night temperatures. Autumn frosts can also stop maize development in September, as occurred in 2005, which was one of four years when mean ear proportion was less than $50 \%(49.5 \%)$.

Maize biomass is not rich in CP. A similar CP concentration in forage yield to our results $(6.7-8.7 \%)$ was reported by Millner et al. (2005) in New Zealand and by Lauer et al. (2001) in the USA for hybrids developed in different decades of the last century. Lauer et al. (2001) concluded that $\mathrm{CP}$ concentration in maize forage had not changed significantly since 1930 .

NDF and ADF are inversely related to important forage quality parameters like intake and digestibility. Lauer et al. (2001) reported that from 1930 to 1990 , owing to progress in breeding, NDF concentration decreased at the rate of $0.825-0.948 \mathrm{~g} \mathrm{~kg}^{-1}$ per year and ADF concentration decreased at the rate of $0.544-0.698 \mathrm{~g} \mathrm{~kg}^{-1}$ per year. As maturity of maize at harvest varied because of the different-maturity hybrids included in the trial in particular years and because of the diverse conditions over the 15 trial years, these differences can be attributed more to the wide range of hybrids in maize maturity at harvest (reflected in the DM content) than to the specific qualities of a particular hybrid, as suggested in another study (Coors and Lauer, 2000). Similarly, also NEL concentration can be more attributed to the diverse maize maturities at harvest.

Starch concentration in biomass also highly depends on the maize maturity stage at harvest. This was the reason why starch concentration in maize dry matter was the lowest in 2009 and 2012, when temperature conditions were only moderately appropriate for maize growing and when DM concentration in fresh yield was low (Table 3). It should also be taken into account that some hybrids (nine in 2012, and five in 2009) included in the trial were from the group having slightly later maturity (FAO above 220), as this may also have affected the observed starch concentrations. Another study (Mussadiq et al., 2012) showed that in similar latitudes (Kristianstad at $56^{\circ} \mathrm{N}$, Sweden) the starch concentration ranged between 23.4 and $31.0 \%$, depending on hybrid earliness, while in more northern latitudes (Skara at $58^{\circ}$ $\mathrm{N}$ and Vasteras at $59^{\circ} \mathrm{N}$, Sweden), a lower starch content was observed for the same hybrids and in the same years. 
Statistical data analysis showed that maize quality parameters at harvest were significantly affected by the trial year (temperature and moisture conditions) and the hybrid used. Nevertheless, the influence of a hybrid can be attributed not only to genetic differences among the hybrids but also to the experimental methods used: the diverse-maturity hybrids included in the trial each year were harvested on the same day, when they had reached different maturity stages. However, the average NDF, ADF, CP, and starch values were similar to those found by other researchers. In future, the influence of a hybrid's genotype on these parameters and hybrid cold resistance in early development stages under conditions of Latvia should be studied more in detail together with different growing management aspects.

\section{ACKNOWLEDGEMENTS}

The research was supported by the Research and Study Farm "Vecauce" of the Latvia University of Agriculture (1999-2013), by the grant of the Latvian Council of Sciences No. 05.1605 .3 (2005-2008), and by the ESF project No. 2009/0225/1 DP/1.1.1.2.0/09/APIA/VIAA/129 (2009-2012).

\section{REFERENCES}

Avižienyte, D., Romaneckas, K., Pališkyte, R., Bogužas, V., Pilipavičius, V., Šarauskis, E., Adamavičiene, A., Vaiciukevičius, E. (2013). The impact of long-term reduced primary soil tillage on maize (Zea mays L.) productivity. Zemdirbyste-Agriculture, 100 (4), 377-382.

Baron, V. S., Oba, M., Aasen, A. (2008). Challenges for growing corn silage suitable for the dairy industry in a northern climate. WCDS Advances Dairy Technol., 20, 181-192.

Barriere, Y., Argillier, O., Michalet-Doreau, B., Hebert, Y., Guingo, E., Giauffret, C., Emile, J. C. (1997). Relevant traits, genetic variation and breeding strategies in early silage maize. Agronomie, 17, 395-411.

Cakir, R. (2004). Effect of water stress at different development stages on vegetative and reproductive growth of corn. Field Crops Res., 89, 1-16.

Coors, J. G., Lauer, J. G. (2000). Silage corn. In: Hallauer, A. R. (ed.). Specialty Corns (pp. 347-392). CRC Press.

Crowley, J. G. (2005). Effect of variety, sowing date and photo-degradable plastic cover on the yield and quality of maize silage. www.teagasc.ie/research/reports/crops/4726/eopr4726.asp (last accessed 5 January 2015).

Gaile, Z. (2009). Maize in Latvia - research during the past century. In: International Scientific Conference: Latvia University of Agriculture - 70, 29 October 2009 (pp. 165-166). Jelgava, Latvia: LLU.

Gaile, Z. (2012). Maize (Zea mays L.) response to sowing timing under agro-climatic conditions of Latvia. Zemdirbyste-Agriculture, 99 (1), $31-40$.

Greaves, J. A. (1996). Improving suboptimal temperature tolerance in maize - the search for variation. J. Exper. Bot., 47 (296), 307-323.

Kosova, K., Haisel, D., Ticha, I. (2005). Photosyntetic performance of two maize genotypes as affected by chilling stress. Plant Soil Environ., 51 (5), 206-212.

Lauer, J. G., Coors, J. G., Flannery, P. J. (2001). Forage yield and quality of corn cultivars developed in different eras. Crop Sci., 41, 1449-1455.
Millner, J. P., Villaver, R., Hardacre, A. K. (2005). The yield and nutritive value of maize hybrids grown for silage. New Zealand J. Agr. Res., 48, $101-108$.

Mussadiq, Z., Hetta, M., Swensson, C., Gustavsson, A. M. (2012). Plant development, agronomic performance and nutritive value of forage maize depending on hybrid and marginal site conditions at high latitudes. Acta Agr. Scand. Sect. B. Soil Plant Sci., 62, 420-430.

Olesen, J. E. (2005). Adaptation to climate change - the case of forage maize. In: NJF Seminar No 380: Adaptation of Crops and Cropping Systems to Climate Change, 7-8 November 2005. NJF Report Vol. 1, No 3 (pp. 49). Odense, Denmark: NJF.

Olesen, J. E., Trnka, M., Kersebaum, K. C., Skjelvag, A. O., Seguin, B., Peltonen-Sainio, P., Rossi, F., Kozyra, J., Micale, F. (2011). Impacts and adaptation of European crop production systems to climate change. Eur. J. Agron., 34, 96-112.

O’Neill, P. M., Shanahan, J. F., Schepers, J. S., Caldwell, B. (2004). Agronomic responses of corn hybrids from different eras to deficit and adequate levels of water and nitrogen. Agron. J., 96, 1660-1667.

Otegui, M. E., Andrade, F. H., Suero, E. E. (1995). Growth, water use, and kernel abortion of maize subjected to drought at silking. Field Crops Res., 40, 87-94.

Peltonen-Sainio, P., Jauhiainen, L., Hakala, K., Ojanen, H. (2009). Climate change and prolongation of growing season: Changes in regional potential for field crop production in Finland. Agr. Food Sci., 18, 171-190.

Ramadoss, M., Birch, C. J., Carberry, P. S., Robertson, M. (2004). Water and high temperature stress effect on maize production. In: Proceedings of the 4th International Crop Science Congress 26 September - 1 October 2004. Brisbane, Australia.

www.regional.org.au/au/asa/2004/poster/1/3/3/1037_madhiyazhaganr.htm (last accessed 5 January 2015).

Reimer, R. (2010). Response of maize (Zea mays L.) seedlings to low and high temperature: association mapping of root growth and photosynthesis-related traits. Dissertation for the degree of Doctor of Sciences, ETH, Zürich, Switzerland. 98 pp

Revilla, P., Malvar, R. A., Cartea, M. E., Butron, A., Ordas, A. (2000). Inheritance of cold tolerance at emergence and during early season growth in maize. Crop Sci., 40, 1579-1585.

Setter, T. L., Flannigan, B. A., Melkonian, J. (2001). Loss of kernel set due to water deficit and shade in maize: Carbohydrate supplies, abscisic acid, and cytokinins. Crop Sci., 41, 1530-1540.

Stanton, D., Grombacher, A. W., Pinnisch, R., Mason, H., Spaner, D. (2007). Hybrid and population density affect yield and quality of silage maize in north central Alberta. Can. J. Plant Sci., 87, 867-871.

Stewart, D. W., Dwyer, L. M., Carrigan, L. L. (1998). Phenological temperature response of maize. Agron. J., 90, 73-79.

Sulewska, H., Smiatacz, K., Szymanska, G., Panasiewicz, K., Bandurska, H., Glowicka-Woloszyn, R. (2014). Seed size effect on yield quantity and quality of maize (Zea mays L.) cultivated in South East Baltic region. Zemdirbyste-Agriculture, 101 (1), 35-40.

Šeremešic, S., Dalovic, I., Milošev, D., Jockovic, D., Pejic, B. (2013). Maize (Zea mays L.) yield stability dependence on crop rotation, fertilization and climatic conditions in a long-term experiment on Haplic Chernozem. Zemdirbyste-Agriculture, 100 (2), 137-142.

Tollenaar, M., Wu, J. (1999). Yield improvement in temperate maize is attributable to greater stress tolerance. Crop Sci., 39, 1597-1604.

Ying, J., Lee, E.A., Tollenaar, M. (2000). Response of maize leaf photosyntesis to low temperature during the grain-filling period. Field Crops Res., 68 (2), 87-96.

Received 7 January 2015 


\section{METEOROLOG̦ISKO APSTĀKḶU IETEKME UZ KUKURŪZAS RAŽAS UN KVALITĀTES VEIDOŠANOS LATVIJĀ}

Latvija atrodas kukurūzas (Zea mays L.) audzēěanas ziemeḷu robežapgabalā, kur labas ražas gadi mijas ar neveiksmīgiem. Šī raksta mērkis ir analizēt kukurūzas ražu, sausnas saturu tajā un dažus citus kvalitāti raksturojošus rādītājus 15 gadu laikā (1999-2013) veiktos lauka izmēǵinājumos Latvijas Lauksaimniecības universitātes mācību un pētījumu saimniecībā "Vecauce" (56 $\left.{ }^{\circ} \mathrm{N}\right)$ atkarībā no temperatūras un mitruma nodrošinājuma. Pētījuma gadu laikā izmēǵinājumos bija iekḷauti kopā 217 dažādi kukurūzas hibrīdi, kas pieder galvenokārt agrīno hibrīdu grupai (t.i., raksturojas ar FAO skaitli līdz 220). Temperatūras un mitruma nodrošinājums pa gadiem bija ievērojami atšķirīgs, bet kopumā desmit gadi uzskatāmi par piemērotiem kukurūzas audzēšanai atbilstoši siltuma nodrošinājumam. Vidējā kukurūzas zaḷmasas raža izmēǵinājumos variēja no 43,01 līdz 63,39 t ha ${ }^{-1}$ un bija 1,8 līdz 2,9 reizes augstāka nekā atbilstošā gada vidējā statistiskā raža Latvijas saimniecībās. Sausnas raža variēja no $8,77 \mathrm{t} \mathrm{ha}^{-1}$ (2004) līdz 20,05 t ha ${ }^{-1}$ (2013) un būtiski korelēja ar vidējo temperatūru maijā - jūnijā. Tādējādi pētījumi pierādīja, ka, vērtējot hibrīdu piemērotību Latvijas apstākḷiem, jāpievērš īpaša uzmanība to aukstumizturībai agrīnajās auga attīstības fāzēs. Gan zaḷmasas, gan sausnas ražu būtiski $(p<0.001)$ ietekmēja gan hibrīds, gan gada apstākḷi un abu faktoru mijiedarbība. Sausnas saturs zaļmasā cieši korelēja ar aktīvo temperatūru summu sezonā. Nokrišņu trūkums vai nevienmērīgs sadalījums bija ražu limitējošs faktors dažos gados. Īpaši nozīmīgi ražu un tās kvalitāti ietekmēja sausums kukurūzas ziedēšanas fāzē. Apkopojot rezultātus, rakstā izvirzīti turpmāk nepieciešamie pētniecības virzieni. 